\title{
8. Torture as a Mode of Governance: Reflections on the Phenomenon of Torture in Papua, Indonesia
}

\author{
Budi Hernawan
}

Torture in Papua, ${ }^{1}$ Indonesia, ${ }^{2}$ gained new attention when graphic footage was leaked to YouTube in October 2010. There are two separate incidents captured in the footage. The first part of the footage depicts eight Papuan highlanders stripped naked of their shirts in front of two Indonesian army soldiers. Two of the victims were identified under the names of Kotoran Wonda and Dipes Tabuni. While interrogating these terrified Papuans and calling them 'monyet', 'anjing' or 'bajingan' (monkey, dog, bastard), the soldiers kicked their heads with their army boots, and hit their heads using their helmets. The soldiers demanded they confess to being members of the Papuan separatist movement OPM (Organisasi Papua Merdeka or Free Papua Movement). The second footage shows two petrified Papuan highlanders: Telangga Gire had a knife at his throat (see Figure 1) and Tunaliwor Kiwo was being burnt on his genitals by members of the Indonesian army to get the men to confess the location of OPM weaponry near the highland town of Mulia. ${ }^{3}$

The leak prompted a wave of international public reaction putting pressure on the Indonesian government to address this atrocity. Instead of showing its usual resistance to international pressure, the Indonesian government responded fairly quickly. Court martials were established in early 2011 in Jayapura, the provincial capital of Papua, to hear the cases. As a result, seven soldiers ${ }^{4}$ were

\footnotetext{
1 This chapter adopts the term 'Papua' which refers to the Western half of New Guinea Island under Indonesia's jurisdiction. It consists of two provinces: the province of Papua and the province of West Papua. 2 This is an advance version of a working paper presented at the Yale Indonesia Forum's workshop on 'New Perspectives on Papua', in New Haven, 15-16 April 2011, and at the 111th Annual Meeting of the American Anthropological Association in San Francisco, 18 November 2012. I thank John Braithwaite, Jeroen van der Heiden, Natasha Tusikov, Robyn Holder and Martin Slama for their critical comments whilst I am solely responsible for any mistakes of this chapter.

3 This footage appeared for the first time on YouTube on 17 October 2010 but then was removed on the following day. On its press release dated 17 October 2010 (http://www.humanrights.asia/news/press-releases/ AHRC-PRL-021-2010), the Asia Human Rights Commission acknowledged that it received the footage and then published it on its website at the same date (http://video.ahrchk.net/AHRC-VID-012-2010-Indonesia. html). Similarly, the Fairfax News Media independently received the first part of footage and uploaded it on the same website (http://www.youtube.com/watch?v=uEisR8rFLOo\&feature=related). By 7 January 2014, the number of viewers reached 143,761 .

4 The cases of seven soldiers were filed in five different dossiers. The first dossier No. PUT/ 186-K/PM.III-19/ AD/IX/2010 includes Private Sahminan Husein Lubis, Private Dwi Purwanto and Private Joko Sulistiono who were all sentenced to five-month imprisonment. The second dossier No. 187-K/PM.III-19/AD/IX/2010 contains the case of Lieutenant Cosmos, the commandant of the group, who was sentenced to seven-month
} 
found guilty and sentenced to jail for five to ten months. The appeal court later reduced the sentence of three soldiers to only three months. ${ }^{5}$ The court did not find them guilty of torture. Rather, they were found guilty of 'not following orders' from their relevant superiors. Similarly, the court found the commandant of the group guilty and sentenced him to seven months not because of torture, but because he 'deliberately provided an opportunity to his subordinates to not follow his orders'. As the verdicts fixed on the matter of 'following orders' the court martial failed to recognise torture as a form of state-sponsored brutality. To make it worse, without any reason the court did not actually try the cases of Kiwo and Gire. ${ }^{6}$ Rather, it only dealt with the cases of Dipes Tabuni and Kotoran Wonda in the first part of the video who were tortured because they were accused of being commandants of the OPM.

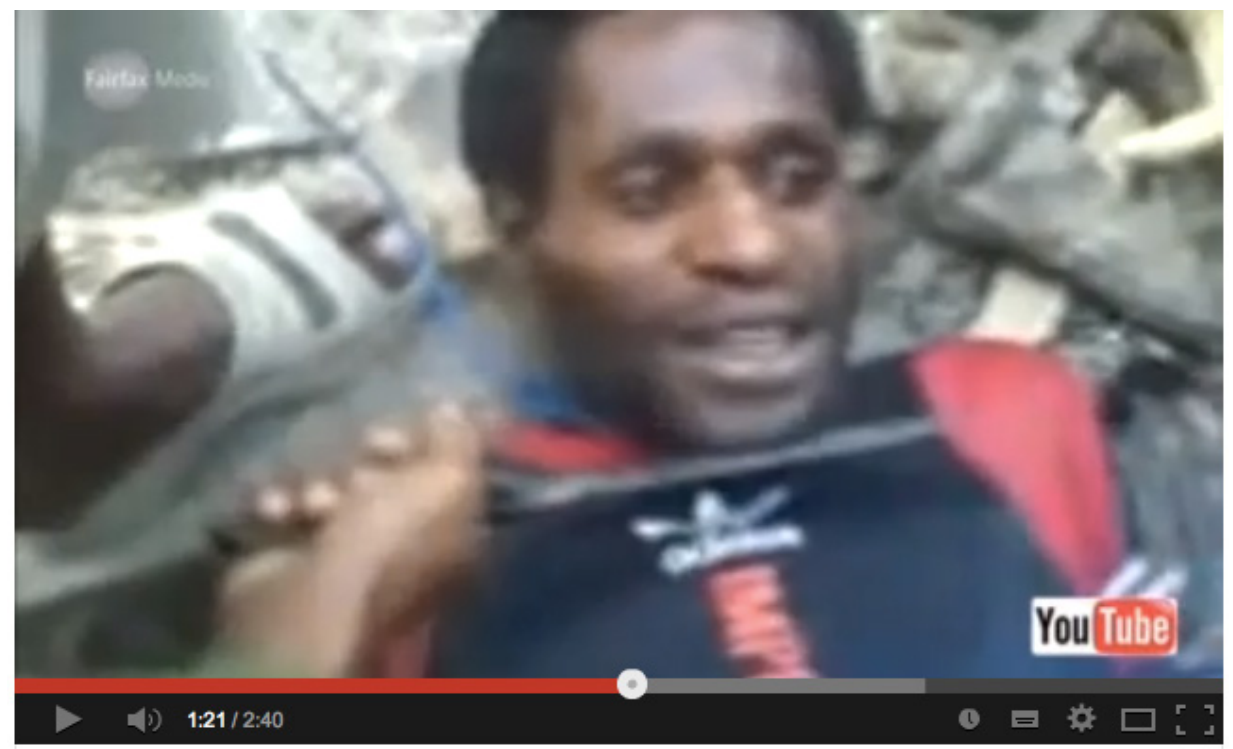

\section{Figure 8.1. Torture video uploaded on YouTube.}

Source: http://www.youtube.com/watch?v=uEisR8rFLOo\&feature=related (accessed 16/01/15).

\footnotetext{
imprisonment. The third dossier No. PUT/03-K/PM.III-19/AD/I/2011 contains the case of Private Tamrin Mahangiri who was sentenced to eight-month imprisonment. The fourth dossier No. PUT/04-K/PM.III-19/ $\mathrm{AD} / \mathrm{I} / 2011$ contains the case of Sergeant Irwan Rizkyanto who was sentenced to ten-month imprisonment. Finally, the dossier No. PUT/05-K/PM.III-19/AD/I/2011 contains the case of Private Yakson Agu who was sentenced to nine-month imprisonment.

5 The appeal court decision No. 66-K/PMT.III/BDG/AD/XII/2010 reduced the sentence of Private Sahminan Husein Lubis, Private Dwi Purwanto and Private Joko Sulistiono from five to three months imprisonment. The other soldiers did not appeal.

6 For the discussion of the confusion of these two separate incidents, see Human Rights Watch analysis at http://www.hrw.org/news/2010/11/21/indonesia-stop-stalling-investigating-torture-video-episode-0.
} 
These verdicts go to the essence of this chapter. It opines that torture in Papua constitutes a state-sponsored crime and has become a mode of governance. Torture, however, is not the only coercive method that is frequently employed by the Indonesian security services to intimidate civilians in Papua and across Indonesia. The Indonesian state apparatus has no hesitation to use killing, surveillance, arbitrary arrest and detention, and disappearances to control civilians.

In this chapter, however, I focus on torture, as this, among a number of other crimes, falls under the category of crimes against humanity under international law. Further, in the context of Papua, the empirical evidence reveals a disturbing pattern of public display that is distinct from what we have seen in the Abu Ghraib model of torture. The latter has prompted the resurgence of scholarly interest in torture in relation to the war on terror (Dershowitz 2002; Dratel 2005; Levinson 2004; Post and Panis 2011). In this literature, torture is used by liberal democracies as part of criminal investigations aimed at collecting intelligence from terrorist suspects with an assumption that the suspects will not willingly provide any information unless they are coerced. Since torture in this context is unlawful and thus any torturer might be held accountable and any information might be deemed inadmissible in court, the Abu Ghraib kind of torture is carefully designed to avoid legal consequences and public scrutiny. That is why this type of torture is commonly hidden from the public.

Torture in Papua is the opposite. The identifiable patterns, such as the one on YouTube, suggest torture is not something very secret. It has been done in public space in the front of a public audience, so anyone, including women and children, can witness an actual event of torture. It suggests the interrelationship of sovereignty and audience. Therefore, it raises fundamental questions such as why the Indonesian security services employ torture in such a public way. What would be the purpose of this brutal method? More broadly, what would be the meaning of employing torture for half a century?

This chapter aims to answer these questions drawing on an analysis of 431 codified cases over the period of 1963-2010. The cases are selected from 12 different non-government sources that have been formally submitted to the Indonesian authorities for prosecution and have become public documents. As a complement, I was also granted access to use two private archives of Papuan specialists ${ }^{7}$ who have done extensive research on human rights issues in Papua. This archival method is largely coupled with face-to-face interviews with three different types of actors, namely torture survivors, Indonesian state authorities and third parties, in order to reconstruct what happened as well

7 I thank Dr Chris Ballard from The Australian National University in Canberra and Reverend Dr Benny Giay from the 'Walter Post' School of Theology in Jayapura who granted permission to use some of their private materials. 
as to explore broader narratives by which these three types of actors perceive and give meaning to torture. This investigation is not limited to Papuans living inside Papua but also the Papuan diaspora who have taken asylum in Papua New Guinea, Australia, the Netherlands, the United Kingdom and the United States. As such, this chapter does not intend to provide a comprehensive history of torture in Papua nor a comparative study on the narratives of torture among three different actors. Rather, I focus on the meaning of torture in Papua as it has been constructed over the period of Indonesian administration since 1963.

In exploring this theme, first this chapter briefly examines the historical and political context in the late 1940s, when the question of Papua was raised in conjunction with Indonesia's decolonisation from Dutch rule. Second, it continues with an analysis of the anatomy of torture in Papua to grasp the nature of coercion. Third, it delves into the meaning of torture. Finally, it discusses the implications of coercive practice as a mode of governance.

\section{Historico-political context of torture in Papua}

The genealogy of coercive governance in Papua derives from the complex power relations that underpin the question of sovereignty in the context of Indonesia's decolonisation from the Netherlands in the late 1940s. I employ the Foucauldian notion of sovereignty as established in Discipline and Punish (1991) and later more developed in Society Must be Defended (2003). This argument contains a number of key terms that need clarification, including 'governance', 'coercion' and 'sovereignty'. The term 'governance' denotes a process of 'societal steering and co-ordination of interdependent actors based on institutionalized rule systems' (Treib, Bähr and Falkner 2007: 3). In other words, governance addresses the question of power relations. Governance is characterised by key elements of political steering and co-ordination between networks. In Foucault's language, governance is framed as 'art of government' to encapsulate his argument that power governs - and in turn, produces - a subject, rather than the other way around (Foucault 1982: 778). ${ }^{8}$ Coercive governance, however, refers to state coercion in which the state resorts to force to build a society and to construct a structure of political domination that extends into all parts of the country. From this perspective, torture constitutes a form of state coercion.

8 In interpreting Foucault's notion of governmentality, Mitchell Dean highlights the core element as 'different rationalities' or different ways of reasoning. Governmentality constitutes an interaction between 'different types of agency and authority and different types of thought' (Dean 2010: 27). Therefore, in Dean's interpretation, the analysis of governmentality centres on the interplay between rationalities (or thought) and technologies (its manifestation in practice). 
The term 'sovereignty' adopted in this chapter is different from that used in the legal and political discourse of the formation of nation states. While legal and political discourse conceives the question of sovereignty in relation to state boundaries and mapping a geographical area, Foucault perceives the same question under the notion of the right over death and life. Sovereignty is manifested through the power of awe and only becomes effective in an action of killing and injuring. ${ }^{9}$ I argue that both the Indonesian security apparatus and Papua freedom fighters have manifested their sovereignty by claiming their rights to kill or injure since the first arrival of Indonesia's administration to Papua on 1 May 1963.

During the first two decades of the formation of the Indonesian nation-state from the 1940s to the 1960s, Papua seemed to be a 'pebble in the shoe' of the foreign relations between Indonesia and the Netherlands. There were three different clusters of power relations competing over sovereignty: first, the Dutch attempted to recreate new boundaries of sovereignty over the former Dutch East Indies by proposing the union of Indonesia and the Netherlands in the late 1940s. Second, Indonesia, as a new emerging nation, asserted its sovereignty over the former territory of the Dutch East Indies, including the then Dutch New Guinea in the early 1960s (Cholil 1971; Dinas Sedjarah Militer Kodam XVII/ Tjendrawasih 1971; Pusat Sejarah dan Tradisi TNI 2000; Soekarno 1962; Yamin 1956). Third, almost simultaneously in the early 1960s, the embryonic Papuan state asserted its sovereignty over former Dutch New Guinea (Alua 2000; Drooglever 2009). These rivalries over sovereignty have not been resolved, notably the dispute between Indonesia and Papuans over control of Papua (Chauvel 2005; Chauvel and Bhakti 2004).

Vlasblom ${ }^{10}$ (2004) documented torture in Papua committed by the Indonesian security forces as early as 1963. This act of injuring was deployed to silence a student protest in Manokwari that was calling for 'one man, one vote'. The protest concerned Article XVIII (d) ${ }^{11}$ of the 1962 New York Agreement ${ }^{12}$ that stated that Papuan adults, men and women, were entitled to cast a secret

9 Further discussions on the relationships between Foucauldian notion of sovereignty and torture can be found in Stephen Morton and Stephen Bygrave (2008).

10 In this chapter, I use an unofficial English translation of the original Dutch version voluntarily provided by a source that wanted its identity to be kept confidential since the translation is solely meant for private and non-commercial use.

11 'The eligibility of all adults, male and female, not foreign nationals to participate in the act of selfdetermination to be carried out in accordance with international practice, who are resident at the time of the signing of the present Agreement and at the time of the act of self-determination, including those residents after 1945 and who return to the territory to resume residence after the termination of Netherlands administration.'

12 The 1962 New York Agreement provided the legal basis to solve the legal and political disputes between the Netherlands and Indonesia on the issue of the sovereignty over Papua involving the United Nations by holding a plebiscite for Papuans. The plebiscite was considered flawed, however (see Alua 2000; Drooglever 2009; Saltford 2003). 
ballot during the plebiscite. The protest was met with harsh measures from the Indonesian military as many people, including university students, were arbitrarily arrested, detained and tortured. The use of these brutal methods to terrorise the whole community increased on the eve of the date of the plebiscite. However, the reported cases from the period of 1962-1969 only constitute a small percentage of the total cases of torture in the last 40 years.

Drawing on notes from an interviewee who was formerly part of an intelligence unit deployed to Papua in 1967, the small figure of recorded cases may indicate the lack of documentation at the time rather than the actual cases that occurred in the 1960s. He explains that he was trained and deployed to carry out intelligence operations for the Indonesian army. 'My role was to identify and arrest OPM members and took them to Kodam. What I did was simply ask them to take a walk with me and they would disappear' ${ }^{13}$ This story suggests that he was part of a bigger system of arresting, kidnapping, torturing and causing alleged suspects to disappear.

Once Indonesia officially gained power over Papua's territory and was met with armed resistance, the use of torture and other brutal techniques intensified. The practice was eventually institutionalised when Papua was declared a Military Operation Zone (Daerah Operasi Militer/DOM) in the 1980s. Many torture survivors and a few former army soldiers explained that a number of military installations around Jayapura, including Ifar Gunung, Kloofkamp and Dok V, were designated to detain and torture anybody who was targeted as an OPM member or sympathiser. However, none of the survivors ${ }^{14}$ could verify whether these places still existed in the 1990s.

On the Papuan freedom fighters' side, the efforts to assert sovereignty over Papua manifested in their frontal armed resistance from 1967 until 1977 when Indonesian security forces succeeded in defeating them militarily. Since then, the OPM has modified its strategy, focusing on low-level armed guerilla tactics, and occasionally launching deadly attacks on military and police installations. At the same time, the notion of Papuan sovereignty has been transformed into a wider political struggle.

After the incorporation of Papua into Indonesia, the Indonesian state regulated Papua under martial law for almost two decades (1980s-1998). This status allowed the Indonesian army to have full control over the territory, resulting in a militarised Papua. The militarisation was not limited to the domain of politics but also law and society. In this context, Papua became exempt from the general legal and political protection provided by the Indonesian state for its citizens. For instance, special treatment as an autonomous region introduced in 1969 with

13 Interview II/E3 in Papua on 4 September 2010.

14 Interviews III/D1 in Papua on 18 July 2010 and III/D7 in Papua on 28 August 2010. 
Law 12/1969 was annulled. Further, in relation to torture, the state of emergency may explain why legal protection against torture within the Indonesian legal system is very limited and thus has played little role in prevention.

Following the dramatic political saga at the national level when President Soeharto stepped down in 1998, Indonesia entered a new phase of reconstructing its power relations with Papua in the spirit of democracy and the rule of law. Reformasi brought about a fundamental change in the relations between the state and society in Indonesia, particularly on issues of civil-military relations. Together with Aceh and East Timor, Papua was granted special autonomy status by the MPR (People's Consultative Assembly), the highest legislative body within the Indonesian legal system. In the context of torture prevention, Indonesia ratified the UN Convention Against Torture in 1998, which opened doors to international scrutiny to assess the situation of torture in Indonesia.

Whilst Reformasi paved the way to demilitarisation of the Indonesian political landscape, some analysts found little change in the nature of the Indonesian military in Papua (Alagappa 2001; Mietzner 2009). A recent study by the Jakarta-based human rights NGO Imparsial (Araf et al. 2011) reveals continuity in the militarisation of Papua by the expansion of the infrastructure and suprastructure of the army and BRIMOB, the police special forces. This evergrowing phenomenon has contributed to the increase of violence and human rights abuses across Papua. This article, however, does not discuss impacts of the militarisation of Papua on a broader spectrum, such as the rule of law, public policy and the daily life of Papuans.

In the past 50 years, Papuan political struggle has been marked by a number of significant occasions on which aspirations for merdeka (independence) have been expressed. More recently, these occasions include the Second Papuan Congress in 2000 that elected a collegial leadership under the name of the 'Papuan Presidium Council' and the recent Third Papuan Congress in October 2011, which was met with harsh measures from the Indonesian security apparatus. The cycle of oppression and resistance has left deep marks on the history and polity of Papua. This is the context in which patterns of torture must be understood.

\section{Anatomy of torture}

The codified cases reveal ten major patterns of torture. First, most of the victims are subsistence farmers, males, civilians and highlanders that live in the rural areas, including the two men in the notorious YouTube torture video. Only a few cases involve victims that were actual OPM members or OPM leaders. Most victims, such as Kiwo and Gire, are innocent civilians and have nothing to do 
with pro-independence movements. They have become 'collateral damage' of a military or police operation ostensibly intended to eradicate the separatist movement.

Another element which features frequently is labeling the torture victims with the notion of animality (monkey, pig, or dog), racial notions (black/ 'hitam') or the notion of underdevelopment (primitive, idiot or stone-age/ 'zaman batu'). In the YouTube video, for instance, the soldiers called Wonda and Tabuni 'monyet, anjing, bajingan' (monkey, dog, bastard). The labels of animality and primitiveness are not uncommon in the daily attitude of Indonesians towards Papuans. Some interviewees, Papuans and non-Papuans alike, suggest ways in which these stereotypes have shaped daily interactions. An Indonesian migrant stated:

The people here are too demanding, don't follow the rule, come to work but don't work, don't want to be developed, and are jealous with the migrants ... we feel sad here of being treated as a second-class citizen by the local government. The government's priority is on the locals whereas the migrants are only in the second ... the Dayaks have the same things. They want independence. The difference is they [Dayak] are committed to work, to learn from the migrants so they are developed; whereas here, if you give them a book to read, they don't want to read it. This is a clear indication that they don't want to learn because books are the source of knowledge. ${ }^{15}$

On the other hand, a Papuan interviewee expressed a similar stereotyping approach to non-Papuans:

I came to Java, got educated in Java until I became smart. I got a job as a public servant in Java, lived in Java, understand Javanese culture and speak Javanese, so that I am able to 'kill' the Javanese ... In a negotiation, you need an argument. If you deal with Javanese using the Papuan ways [that rely on physical force], definitely you'll lose [the negotiation] because an argument doesn't match [physical force] ... I often hear people call me 'black, monkey, [and say] kill him'. This made us hate each other. This pushed us to fight to death. ${ }^{16}$

The labels have influenced their relationships with a sense of prejudice, distrust, disgust and frequently arrogance and hostility. ${ }^{17}$

15 Interview with a civil servant II/C11 on 2 August 2010 in Papua.

16 Interview with a senior state prosecutor II/C20 on 26 August 2010 in Papua.

17 For a critical analysis on the correlations between primitive labeling and justification of militarisation of Papua, see Kirsch (2010). 
In the context of torture, however, these stereotypes are woven into the architecture of state brutality so that the impact of violence can be more destructive. These labels inform the mindset of the torturer and might help neutralise his sense of morality that resonates with Kelman's (2005) theory of crimes of obedience discussed below.

Second, the fact that rape features as a preferable method to sexually torture Papuan women is striking. Twenty-eight per cent of female survivors have been raped while 5 per cent experienced other forms of sexual torture without rape. Thirty per cent experienced non-sexual torture. The phenomenon might be related to the strategy of conquest introduced by the Indonesian state when it gained control over Papua in 1962. This correlation between rape and war resonates with a broader pattern of the use of rape as a weapon of war in a combat zone.

The recent joint study project by National Commission on Violence against Women (Komnas Perempuan), International Center of Transitional Justice (ICTJ) Indonesia and Papuan People's Council (Majelis Rakyat Papua/MRP) sheds new light on this issue (Komnas Perempuan 2010). It covers the period of 1963-2009 and examines 261 files of violence against Papuan women. The study found two major types of violence, state violence in 138 files and domestic violence in 98 files. Fourteen women suffered both forms of violence. Eleven women suffered from communal violence. The study not only confirms the pattern of security sector rape, but shows how Papuan women are vulnerable to multiple abuses even in their own families, which are supposedly protective of their safety and wellbeing.

Third, torturers are mostly members of the Indonesian state security apparatus: TNI (The Indonesian Armed Forces) and the Police. They are 65 per cent military personnel, 34 per cent police officers and only 1 per cent militia. The YouTube video exhibits this pattern. This finding is disturbing because it reveals that the Indonesian state apparatus has become a major agent of terror and brutality. Instead of delivering services and protection, the Indonesian state apparatus is willing to resort to terror and brutality as a mode of governance rather than to legal and democratic procedures. Put into the horizon of the history of Papua, this reality is even more disturbing as the practice has been basically unchallenged in the last 50 years.

Fourth, techniques of torture are inexpensive and require no skill. The most frequently used physical torture is 'beating', followed by 'kicking'. This might be related to the fact that, generally, the Indonesian security services are underpaid, provided with poor equipment and minimal facilities to carry out their duties. So the members of the military and the police can only use whatever 
is accessible such as their own hands and legs, guns or other equipment that is available on the spot (see Rejali 2007). The following testimony during courtmartial hearings provided by soldiers illustrates the simple methods.

... The indictee became irritated and hit the head of Mr Dipes Tabuni, the commander of the resistance, with his helmet one time, kicked $\mathrm{Mr}$ Dipes Tabuni's back with his army boots ... ${ }^{18}$

Torture as a technique is simple and cheap but when the technique is interwoven with a sophisticated architecture of domination, the impact can be devastating.

Fifth, torture in Papua regularly takes place based on unproven and one-sided accusations by the Indonesian security apparatus. These include accusations of killing members of security services or company employees (e.g. of the mining company PT. Freeport Indonesia or timber companies), accusations of being a member of the OPM and accusations of attacking government installations. It is obvious that accusations alone have been considered sufficient for the torturers to commit offences in Papua during the last half century as we learn from Kiwo's testimony below:

And then they demanded ... 'You have to be honest!' ... 'You have to be honest!' ... But I don't know anything, I'm just a regular person ... over and over again ... but they kept pushing me ... You're lying, you have to tell the truth that you're OPM, right?' ... we were constantly pushed that we were so confused to talk, we were numb and our voice was trembled, we couldn't answer properly because we were nervous ... eventually they kept torturing me ... repeatedly ... back and forth beating me from head to toe while my hands and feet were already in tied position ... I've become powerless ... ${ }^{19}$

Furthermore, accusation or labeling has also become the basis of legal proceedings that have led to the imprisonment of torture survivors. These accusations function as an excuse for the TNI and the police to inflict great pain on the bodies of the suspects. These examples suggest that torture in Papua is mostly politically motivated and is justified by the Indonesian security apparatus as acts against anyone who is perceived as an enemy of the Indonesian state. Therefore, it is predictable that any individuals associated with OPM are likely to be subjected to torture when they confront the TNI or the police. On the other hand, accusation as the basis for torturing Papuans reveals the lack of professionalism of the Indonesian security apparatus. Allegations should be dealt with through professional investigation as part of the rule of

18 See the court martial decision No. PUT/ 186-K/PM.III-19/AD/IX/2010 para 9 page 20.

19 For full transcript of Kiwo's testimony see http://www.engagemedia.org/Members/dewanadatpapua/ news/kiwotranscript-en (accessed on 28 June 2013). 
law. The widespread use of torture not only strengthens the perception of the implementation of the state of abjection in Papua but also undermines the ability of the Indonesian judiciary to uphold the rule of law as part of Indonesia's democratisation. ${ }^{20}$

Sixth, under conditions of lawlessness and political transition, the Indonesian state apparatus has heavily relied on torture as a technique to handle secession movements. Over the period of 50 years, the pattern of torture is as follows: out of 431 codified cases of torture, 42 per cent occurred during Reformasi, which is the period between the fall of Soeharto's New Order in May 1998 and the enactment of the Special Autonomy Law for Papua in November 2001. This transition period records the highest frequency of torture. It is followed by the second highest (37 per cent) during the New Order period (1967-1998) and the third highest in the present Otsus era which constitutes 19 per cent of the total figure. The lowest figure can be found in the Soekarno period (1963-1967), which only constitutes 2 per cent of the total. However, another explanation of these findings relates to the involvement of local people in reporting torture (a pattern described subsequently) and to the fact that during Reformasi Papuan civil society gained momentum to operate with far greater freedom to monitor and document cases of torture across Papua as well as to expose them to the attention of the broader public.

Seventh, drawing on the judgments of the International Criminal Tribunal for Yugoslavia (ICTY) and the International Criminal Tribunal for Rwanda (ICTR), such a long-term and unpunished practice of state-sponsored torture can only be possible if there is a plan or policy (Boot 2002; Hansen 2011; Schabas 2006). The Papuan torture practice has repeatedly targeted Papuans, i.e. mainly farmers, male, civilian and highlanders, in the last 50 years. The practice has only involved members of the Indonesian state security services as perpetrators and their facilities, which implies the involvement of high-level political and/ or military authorities. The torture dataset records 431 cases of torture, suggesting a large scale of unpunished acts of torture.

Eighth, cases of public torture constitute 82 per cent of the total number of cases whereas only four per cent occurred in private (14 per cent in unknown locations). This pattern shows the central element of a spectacle: public display of the injured Papuan body. Location matters here. Drawing on this evidence, it can be argued that the power of spectacle does not lie in the act of inflicting actual pain and suffering but more in the act of communicating such an experience through the display of mutilated bodies (Rothenberg 2003). ${ }^{21}$

20 Concerning the concept of abjection see my discussion of Kristeva (1982) below.

21 The interaction of public display of power and its audience is a complex theoretical issue which requires separate discussion to ponder its nature. This problem not only resonates with Rutherford's (2012) analysis of the positive intercorrelations and reciprocity between sovereignty and audience but also with a broader 
The eighth pattern becomes very relevant with the distribution of digital video footage, as this constitutes a distinctive phenomenon in Papua that is not found in other torture situations in Indonesia, such as those involving drug dealers (Nowak 2008) or terrorist suspects. Most of the torture files I analysed describe the torture being committed in a public arena, such as on city roads, in the backyards or front yards of Papuans' homes, the marketplace and other open areas that are accessible and visible to anybody, including women and children. For example, the martial court verdict states that according to the confession of the convicted soldiers, the women and children were only 50 metres away from the crime scene and only separated by huts and trees. It was highly likely that they could have heard the screaming of the victims. This pattern has identified the public space as the locus of torture. ${ }^{22}$

In the case of torture committed in military and police compounds, many victims were tortured in open areas inside the compound. Public display of bodies is not unique to Papua. A similar method has been employed by the Indonesian state in various contexts, such as in Aceh (Aspinall 2006; Rahmany 2001), in former East Timor (CAVR 2005: 259-260, 310-11) and to 'combat criminals' in the 1980s in various places, where dead bodies were left in public for display (Soeharto 1989: 389-390). However, in Papua the torturers keep the bodies alive so they can transmit and amplify the terror to Papuans as a community. Yet unlike the Papuan social body, the international audience is clearly not the target of the message from the sovereign power, as the YouTube video shows. This audience has been inadvertently exposed to the brutality of the torturers, but did not succumb to the shock and awe produced by the sovereign power of Indonesia. Thanks to communication technology, the international audience amplified the call for justice from the torture survivors and generated strong pressure on the Indonesian authorities which led to the prosecution of the torturers - rather an exception than the rule, as the next characteristic shows.

Ninth, the element of colonisation of public space that has led to almost complete impunity constitutes an important characteristic of Papuan experiences of torture. Seventy-one per cent of the torturers have never been brought to justice and 5 per cent of those who were brought to court were eventually acquitted, whereas 24 per cent of cases have been pending. Despite the TNI reform agenda

discussion of the multifaceted ambiguity of witnessing torture (Cohen 2001; Graziano 1992; Taylor 1997). In his study of an abstract audience of torture in Argentina's Dirty War, Frank Graziano (1992: 78) identifies the range of the notion of witnessing from gazing in a literal sense to a symbolic sense and an abstract sense. In a literal sense, witnessing means seeing and even engaging with an actual event. In a symbolic sense, witnessing is watching a representation of a torture event mediated and filtered by the media. In an abstract sense, however, witnessing can only draw on an idea of torture based on knowledge of sites and events of torture although this knowledge is suppressed or surrounded by denials.

22 See the court martial decision No. 187-K/PM.III-19/AD/XI/2010. 
sanctioned by law, the territorial command structure ${ }^{23}$ remains unchallenged (Reiffel and Pramodhawardhani 2007). In the Papuan context, this fact suggests that the strategy of militarising Papuan space will continue in the near future.

The tenth characteristic of torture in Papua is that local actors play a more dominant role in exposing torture than international actors. Churches and local NGOs reported 80 per cent of torture cases, while international NGOs exposed the remaining 20 per cent of cases. This statistic indicates the capability of local actors with regard to confronting torture in Papua.

\section{Making sense of torture}

The chief patterns of torture outlined above resonate with the analysis of torture that Foucault uses to explain the public execution of Robert Damiens, a regicide, in 1757 in Paris as an opening of his Discipline and Punish. Foucault (1991) argues that under the order of the King, the executors tortured Damiens to death in front of Parisian spectators to signify the unrestrained power of the King. This was a 'power that not only did not hesitate to exert itself on bodies, but was exalted and strengthened by its visible manifestations' (Foucault 1991: 57).

It was the effect ... of a certain mechanism of power: of a power that not only did not hesitate to exert itself directly on bodies, but was exalted and strengthened by its visible manifestations; of a power that asserted itself as an armed power whose functions of maintaining order were not entirely unconnected with the functions of war; of a power that presented rules and obligations as personal bonds, a breach of which constituted an offence and called for vengeance; of a power for which disobedience was an act of hostility, the first sign of rebellion, which is not in principle different from civil war; of a power that had to demonstrate not why it enforced its laws, but who were its enemies, and what unleashing of force threatened them; of a power which, in the absence of continual supervision, sought a renewal of its effect in the spectacle of its individual manifestations; of a power that was recharged in the ritual display of its reality as 'super-power' (Foucault 1991: 57).

In Foucault's view, the ritual of public execution is a manifestation of technologies of power in which visibility is a conditio sine qua non (an absolutely necessary condition). The ritual was a public exhibition of graphic atrocity to maximise the visibility effect and to minimise misinterpretation from the

23 Despite the 1998 Reformasi which paved the way to institute democracy led by a civilian government, the Indonesian military remains preserving its physical infrastructure across the country under the territorial command structure. This structure runs parallel to the civilian government from the sub-district to the national level. 
audience. Power is a sacrosanct quality inherently embedded in the personality of the King. Any sign of disobedience constitutes an act of rebellion, which is punishable by agonising pain, leading to disgraceful death as exemplified by Damiens. By commending this sort of public execution, Foucault argues, the sovereign recharges its power. Therefore, the ritual of public execution of Damiens is not only meant to transmit the message of the sovereign power to the Parisian audience but also to reinforce the power of the King.

In a similar fashion, since 1963, the Indonesian security apparatus has employed torture to demonstrate the unrestrained power of a state that is willing to take any necessary measure to assert sovereign power over Papua. Torture has become a manifestation of the right to kill and to injure in a Foucauldian sense. In this context, any sign of opposition is deemed intolerable and will meet harsh measures from the Indonesian state. Papuan resistance is never tolerable as it seeks to compete with the sovereign power of the Indonesian state in asserting its rights over Papua. The Indonesian state apparatus manages to control the entire landscape of the Papuan social body and it has little fear of being held accountable. This power has infused terror into the social body by leaving scars on particular Papuan bodies and on the collective memory of Papuans. Therefore, such power shows little intention to hide what it has committed because it defines the meaning of killing and injuring as a form of power. That is also the reason why such power needs only 'accusation' to justify its brutality. Moreover, graphic punishment has the effect of renewing Indonesian sovereignty.

The Foucauldian analytical framework helps explain the phenomenon of the public display of torture in Papua in that such acts signify the way in which the state apparatus communicates to the broader audience. As torturing Damiens' body is not an end in itself, neither are the tortured Papuan bodies. Rather, torture is a medium that carries the message of the Indonesian state's unrestrained power to the broader audience of Papuan society. This is the real target. The whole society has to feel and to experience the intrusion of the sovereign power of the Indonesia state so that all members will understand that any sign of opposition will not be tolerated.

The fact that Indonesian security forces no longer maintain their 'torture chambers', hidden places within military and police stations designated to torture Papuans around Jayapura, but rather, practices torture in plain view, affirms the symbolic power of torture. The public practice of torture takes place in a context in which security forces are increasingly occupying public space in Papua. The territorial command and the heavy presence of the army from the village level to the provincial government administration level have been effective in transmitting the message of the pervasive influence of the Indonesian state. Even though there is growing public scrutiny from the emerging human rights monitoring regime in Indonesia, the latter has not been able to eradicate torture as a mode 
of the production of meaning constructed and maintained by the Indonesian state apparatus. The military institution continues to perform its role as a quasigovernment vis-à-vis the democratically elected civilian government.

What is the impact of the unrestrained power on individuals? Whilst the Foucauldian framework provides a useful means to explain processes at the structural level, it has limits to answer these questions. Therefore, I draw on Kristeva's (1982) notion of the abject that provides a theoretical framework for explaining a process of dehumanisation, ${ }^{24}$ such as torture. In her Powers of Horror, she coins the term 'abject' as a metaphor to explain the construct of nonperson, an entity between subject and object, which is rejected both by subject and object. The abject equals non-existence (Kristeva 1982: 1). Kristeva underscores the notion of the abject as an opposition to the subject or ' $\mathrm{I}$ '. The notion of 'otherness, detached, non-correlative, autonomous' suggests a stark contrast between $I$ and the abject but also a total separation. The subject, however, claims and retains the abject at the border between subject and abject in order to form the existence of the abject.

So how does Kristeva's theory of abjection help explain torture in Papua? The unrestrained power of the Indonesian state not only controls Papuan society but also inscribes its power over bodies. Torture constitutes a physically harmful act that aims to destroy the subjectivity and agency of Papuans. By targeting the lowest class, ethnicity, non-combatants, more men than women, torture has turned these individual Papuans into non-existence. It has infused the notion of meaninglessness and formlessness into these people so that they lose control over their own subjectivity.

The loss of subjectivity is reflected in the experience of torture survivors who express loss of trust and disconnection from others. For instance, one interviewee shared her stories on how she lost her ability to talk after being subjected to torture. ${ }^{25}$ The survivor was not only subjected to excruciating pain which seriously damaged her body but also, torture crippled her capacity to express her pain to her community. As a result, her story has never been heard. The survivor becomes an invisible and impenetrable being because language, the bridge between the survivor and the world, has been destroyed. Kristeva's analytical approach helps explain one of the most extreme processes of dehumanisation that occurs at the individual level when an individual is subjected to torture.

The practice of torture suggests that the Indonesian state regards Papuans in abject terms as undesirables who are nonetheless useful for marking the boundaries of

24 Elaine Scarry's (1985) The Body in Pain provides a similar analytical framework for explaining the internal dynamics of torture at the individual and personal level. However, her work is more relevant for hidden torture as part of coercive efforts to gain intelligence information or to obtain confessions.

25 Interview with a torture survivor II/A20 in Papua on 11 August 2010. 
the sovereign state. On the one hand, as an abject, Papuans are being excluded to the margins of the Indonesian state but on the other hand, they continue to be claimed and retained tightly as a non-negotiable entity. As part of the abjection process, Papuans have also experienced dehumanising treatment by being labeled as 'monkey' or 'stone-age people'. On the YouTube video, we can hear one of the soldiers clearly calling the victims 'monkey'. Although these stereotypes are not the basis of torture, they have informed the mindset of the Indonesian security apparatus to neutralise their moral conscience so that torturers perceive that they only torture non-humans, situated one level below the torturer's self-identity. This process will be further elaborated in the following section of this chapter.

The process of dehumanisation is never entirely complete. As Kristeva argues, the abject inherently contains resistance. This energy enables the abject to confront the subject by attempting to penetrate the boundaries between the abject and the subject. That is why the abject can 'revolt'26 in Kristeva's terms. This element also explains why Papuans continue their revolt despite the oppression from the Indonesian state. Papuans, as the abject, inherently possess the energy to resist. So while they will not be entirely destroyed, they will continuously pose a threat to the Indonesian state. In contrast to Kristeva's prognosis, however, Papua's experience suggests that the abject is more than capable of crossing boundaries and asserting aspirations for merdeka. Papuans are not entirely turned into powerless abjects; they manage to penetrate the boundaries of the Indonesian sovereign power by expressing their claim for sovereignty.

The production of the meaning of torture is not a single event. The meaning of torture is produced dialectically. The exercise of the right of the sovereign to injure generates an incremental process of dehumanisation in the form of the abject. As a response, the abject revolts and exerts its energy to resist, which meets increasing force from the sovereign. This dialectic generates a vicious cycle of violence, which we have seen in the history of Papua. The arrival of the Indonesian administration generated oppression that met revolt from the Papuan freedom fighters. This revolt has been met with greater oppression from the Indonesian state, which reinforces and maintains its rights to kill and to injure.

Torture has become an integral part of governing Papua since the Indonesian state took over the territory. The state apparatus has used torture to steer and to co-ordinate social dynamics in Papua, which are characterised by resistance and low-level armed struggle. These coercive methods lie beyond traditional models of parliamentary governance, but they are sanctioned nonetheless. Because of this, we might conclude that torture has become a mode of governance.

26 In Kristeva's Revolt, She Said, she defines the term 'revolt' distinct from 'revolution'. She states, 'I work from its etymology, meaning return, returning, discovering, uncovering and renovating. There is a necessary repetition when you cover all that ground, but beyond that, I emphasize its potential for making gaps, rupturing, renewing. Rebellion is a condition necessary for the life of the mind and society' (2002: 85). 


\section{Internal dynamics of governance through torture}

Torture is a medium that can transmit and amplify the awesomeness of power. The main point is to communicate a message from the sovereign to the whole community through the injured body (Rothenberg 2003). This message must be made very explicit and blunt so as to avoid any misinterpretation. It is important to consider how torturers become enlisted in carrying out the state's message, because this reveals some of the internal dynamics within the state structure that lead to torture. How do state agents become torturers? Why are they willing to engage in heinous acts and show little remorse for such a long period of time? My analysis of the Papua torture files reveals what Herbert Kelman (2005) calls, 'crimes of obedience'. Kelman (2005: 124) argues that an analysis of torture should 'go beyond the characteristics of the individual perpetrators or even of the situation in which torture is practiced, and focus attention on the larger policy context in which the practice of torture is embedded'. Therefore, he defines torture as 'a crime of obedience: a crime that takes place, not in opposition to the authorities, but under explicit instructions from the authorities to engage in acts of torture, or in an environment in which such acts are implicitly sponsored, expected or at least tolerated by the authorities' (Kelman 2005: 125).

Torture is facilitated by doctrines of state legitimisation: maintaining law and order or stability, the rule of 'the people' whom the state claims to embody, or national stability. Agents must believe that they are part of a 'transcendent mission, a task that serves a high purpose that transcends any moral scruples they might bring to the situation' (Kelman 2005: 131). In the case of Papua, the territorial integrity of the Unitary State of Indonesia remains a sacrosanctum that justifies any means to be upheld.

In this process, Kelman proposes, the agents of torture are defined as a professional force with a significant role in protecting the state against internal threats to its security. In Papua, the torture case files reveal that torture takes place in the absence of professionalisation because the indoctrination of agents' purpose in protecting the state is so powerful. With the exception of the Indonesian Army Special Forces (Kopassus), most units of the Indonesian security services are poorly funded, poorly trained and underpaid. In this context, they might not be trained as torturers per se but they have to undergo a rigorous process of indoctrination and socialisation to obey any orders coming from superiors and to embrace the Indonesian state doctrine 'NKRI harga mati' (the territorial integrity of Indonesia is non-negotiable). The following testimony of an ex-army soldier may exemplify this pattern: 
My job at the time was in charge of combat intelligence unit and had to be in disguise. The training I had to take was really really heavy: trained to steal documents like a pick pocket without being spotted and all sorts of other training. In Papua, my job was to arrest members of the OPM and take them to KODAM. So I invited him to take a walk with me around here and then disappeared. Another unit took him. This applied to the hardliners but for those who were more approachable, we provided vocational training on agriculture. ${ }^{27}$

The emphasis on the 'really really heavy' training illustrates the rigorous process to develop his professional skills. Although he did not specifically mention torture, his testimony captures a systematic way to target those who were considered 'hardliners' and those who were 'approachable'. This categorisation led to serious consequences because the hardliners were 'disappeared' while the approachable were spared and given agricultural training instead. In other words, the categorisation is not simply an administrative classification but all about life and death, which resonates with Foucault's interpretation of the public execution of Robert Damiens.

Torturers may participate in sanctioned violence because the targets of torture are defined as enemies of the state who constitute serious threats to the state's security and survival. When Papuans are positioned as OPM, as inferior, or as estranged from mainstream ethnicity and culture, they are placed outside the protection of the state. Papua was under martial law during Soeharto's New Order regime until 1998. This status suggests that the Indonesian state identified the Papuan resistance movements as its enemy. However, the first pattern of the anatomy suggests that the treatment is not limited to the OPM but applies to any Papuans, particularly those who are most vulnerable: subsistence farmers, highlanders and women, who are imbued with the notion of animality and primitiveness. Whilst martial law was lifted in 1998, legacies of treating Papuans as enemies have changed little, as we can see from the YouTube video.

At the level of implementation, Kelman (2005: 131) states, 'The justification of torture as a means of protecting the State against threats to its security helps to authorize the practice; the development of a profession of torturers as part of the State's security apparatus helps to routinize the administration of torture; and the designation of the targets of torture as enemies of the State who are excluded from the State's protection helps to dehumanize the victims.'

These three social processes contribute to weakening the moral restraints against engaging in torture and other gross human rights violations because authorisation abolishes any responsibility to make any personal moral choices on

27 Interview with a retired Indonesian army officer III/E3 in Papua on 4 September 2010. 
the basis of standard moral principles; routinisation enables them to ignore the overall meaning of the task they are undertaking and eliminates opportunity to raise moral questions; dehumanisation excludes victims from the perpetrators' moral community, making it unnecessary to relate them in moral terms. The failure of the court to try Kiwo's and Gire's cases and the similar failure to present any victim witnesses ${ }^{28}$ before the court of Wonda's and Tabuni's cases illustrate the exclusion of Papuans from the moral community of the perpetrators.

The following excerpt from a police interviewee might illuminate the element of routinisation that has neutralised any personal moral choices, particularly the sense of guilt:

Torture is still everywhere but notably in Papua because of the low level of education of the police officers. Hit [a suspect] first, then interview [him/her]. Such a thing still exists in Java too. When I was in the police academy, I saw our senior put a table foot on a suspect foot. The table was made of steel. Of course, the foot was punctured. Or pulling fingernails. But it changed now. It leaves no marks. Slapping or punching doesn't leave any mark. You wash your face and it's gone. So the practice remains but using 'pola manis' (smooth methods).

The police academy contaminated my attitude. I used to be a bad boy with violent behaviour but had stopped before joining the police force. When I did my training at the police academy my past behaviour came back because of the atmosphere. I did shoot a criminal so he had to have amputation but that's it. I stopped. I have not hit anybody including my boys since then because if an officer hits somebody, his soldiers will follow his example. ${ }^{29}$

He acknowledges that the rampant practice of torture has a direct connection with the atmosphere of the Indonesian police academy where he had received his training. As a result, his past violent behaviour was revived. He learnt how to deal with criminal suspects by witnessing the ways his seniors used methods of torture to obtain confession from suspects, which in fact were considered a common practice.

In other words, he acknowledges that his formation ${ }^{30}$ has laid the ground for justification of a policy of torture. It has a direct causality with the practice

\footnotetext{
28 The decision of the court martial of appeal specifically mentioned the absence of witness testimonies as one of the legal flaws of the first court martials hearings: ' $\ldots$ and in fact, since the court hearings adjourned until the verdicts were delivered, civilians, who had become the victims, were never been presented before the court ...' See the decision of the court martial of appeal No. 66-K/PMT.III/BDG/AD/XII/2010 page 12.

29 Interview III/C16 with a middle ranked police officer in Papua on 18 August 2010.

30 In his recent doctoral thesis on professionalism of the Indonesian military, Robertus Purwoko Putro (2012), an Indonesian airforce middle-ranking officer, concludes that the problem of impunity is deeply entrenched
} 
of dehumanising suspects, who were not entitled to protection from the state. Further, torture was considered commonly practiced by his seniors who authorised these brutal methods to be used by their subordinates. His seniors lifted any moral constraints and responsibility that might have deterred the use of torture. Authorisation and routinisation have led to dehumanisation of suspects as forms of crimes of obedience (Kelman 2005).

The police officer's story exemplifies how the in-group (Post and Panis 2011; Janis 1972) generates enormous pressure for uniformity in action among members of the police academy and overrides any moral constraints and personal judgments because they perceive the criminals as the enemy.

Another story from a senior army officer suggests a completely different element in ways in interpreting 'the enemy'. He identifies the MRP (Papuan Peoples' Assembly), ${ }^{31}$ a state institution in Papua, as a threat to Indonesian power, and the state of mind of being colonised as a challenge to the Indonesian state.

MRP does not follow its role and has stepped into a political domain by issuing Decree No. 14. An election belongs to the political domain. They intervened and endorsed a regulation that the regent and its deputy have to be indigenous Papuans. Otsus itself only applies such a thing for the governor and its deputy. Even so, is it the right time to issue such a decree when the district election is only 3 months away? Is it true that it was MRP who issued the decree? MRP 'handed back' Otsus whereas this institution itself comes from Otsus. The Chairman [of MRP] explained it happened because of the huge pressure from the people. But they issued a letter on behalf of the 'Papuan nation'. They use the word 'nation' not 'tribe'. This actually reflects their dissatisfaction.

A real challenge, apart from heavy terrain, is an image of being colonised: how to convince the people that they are not colonised? How to address the stigma of being strangers? How to convince the people that TNI here is not a coloniser? The migrants are not colonisers either. This is the real challenge for us whereas those enemies in the jungle will realise that what they did is wrong. ${ }^{32}$

These excerpts represent a much more sophisticated analysis of how the Indonesian army defines the enemy of the state, precisely by identifying a defiant element and state of mind. He did not refer the OPM as a threat or a challenge. For him, MRP is a real threat because it possesses a state power

not only into the structure of the Indonesian army but, more importantly, in its psyche. In combination with the historical legacy of the military domination in Indonesian politics particular during the New Order, the culture of impunity within the Indonesian military has seriously undermined their professionalism.

31 The interviewee specifically referred to the MRP from the period of 2005-2010.

32 Interview with a senior army officer II/C24 in Papua on 2 September 2010. 
to formulate legislation that has legal and political bindings. The challenge he describes is also sophisticated. Instead of referring to security or military threats, he points to the Papuan state of mind of being colonised. His comments indicate a higher degree of analysis to legitimise torture, which is not found in previous legitimation for torture.

The officer's comments offer a personal perspective on how the doctrine of territorial integrity of Indonesia is nonnegotiable. The doctrine serves as a mind guard that puts pressure on members of the state apparatus not only to support the doctrine but more importantly, to be the vanguard of the doctrine.

Internal governance dynamics not only shape the practice of torture at the level of the individual practitioner, but the situation of Papua puts strain on Indonesia's democratic emergence. While Kelman (2005) states that torture is endemic in the autocratic state but less likely to take place in democracies even though there is no guarantee for it, Darius Rejali's (2007) work on the correlations between torture and democracy shows that torture not only can occur within a democratic framework but even inevitably co-exist.

Rejali (2007) identifies three reasons why torture coexists with democracies that help elucidate why torture in Papua has increased, not decreased, during Indonesia's new democratic era. In some cases, 'officers practice torture as part of a proactive strategy to combat an enemy in an emergency. Victims may be local or foreigners, but they are always chosen because of their suspected political activities' (Rejali 2007: 49). This also suggests that democratic transitions are often marked by violence and instability, which promotes and enables 'emergency' measures. In other cases, 'torture enters democracies through a legal system that highly values the confession of the accused' (ibid. 50). Torture may also coexist in democratic countries because the democratic state is unable or unwilling to provide public security, perhaps because the territory is too great or its resources too limited' (ibid. 57). Torture, Rejali (ibid.) argues, 'generates different disciplinary orders, sharpening differences among human beings'. The bottom line is the differentiation between citizens and non- or quasi-citizens, in which citizens are imagined to possess virtue while non- or quasi-citizens do not. Those who do not possess virtue can be subjected to torture as they are not entitled to state protection. The labelling of Papuans as 'monkey' and 'idiot' encapsulates the notion of Papuans being non-persons who do not possess the same virtue as other Indonesian citizens.

Nonetheless, this research suggests that it might be a long way to go for Indonesian authorities to be able to eradicate the practice of torture in its policies towards Papua and across Indonesia because, borrowing Rejali's terms, the Judicial Model and/or Civil Discipline might replace National Security institutions as the source of torture. 
Torture has become a mode of governance as it constitutes a social policy applied to the Papuan community. Torture has been institutionalised through the state bureaucracy, military and police structures, as well as intelligence services. Further research needs to examine the impact of torture as a mode of governance on education, judiciary, health and cultural systems.

\section{Conclusions}

The prolonged practice of torture in Papua has generated spectacles of shock and awe. These spectacles derive from the ways in which the Indonesian state exercises its sovereign power over Papua through public displays of torture. The phenomenon of torture is deeply embedded in the policies and practices of the Indonesian state apparatus in dealing with Papuans. The recent distribution of torture videos from Papua on YouTube underlines the fact that the practice of torture in these easternmost provinces of Indonesia remains. The justice system continues to fail in addressing the practice.

However, the spectacle of awe is not the ultimate goal of state-sponsored brutality. Rather, it is designed to send a very clear message of the presence of unrestrained power of the state that reaches far beyond the Indonesian security sector. As a network of power we can suspect that it may infuse the Indonesian government bureaucracy, the education system and development policy. Totality of control based on coercive governance is the ultimate goal of torture-as-awe.

Aside from control, the torture also aims to dehumanise Papuans and turn them into the abject. This mechanism is expressed in the notions of animality, primitiveness and racism during events of torture as recorded in the YouTube footage. The dehumanisation, however, is not simply an individual and incidental act. Rather, it is informed during the professional development of the Indonesian security apparatus and thus habituated and institutionalised through practices and indoctrination of the Indonesian state ideology. Furthermore, the dehumanisation facilitates the treatment of Papuans as quasi or even noncitizens in that this group of people are not only placed outside the protection of the Indonesian state, but more importantly, are considered incapable of meeting the standards of civility of the Indonesian citizens. Therefore, it is not only that they are treated as non-citizens, but more importantly, torture is considered the only means to discipline them.

Despite the overwhelming influence of the power of torture over Papuans, the recent distribution of the YouTube video suggests something else as well. This kind of spectacularity invokes unintended consequences for the sovereign once it is exposed to a different audience. Instead of reproducing and intensifying 
the existing terror for the Papuan audience, its widespread distribution to the international audience has inadvertently provoked backlash which eventually pressured the Indonesian state to hold the perpetrators accountable.

For over 50 years, this form of governance has produced and reproduced crimes of obedience that, in turn, have reinforced the totality of coercion. Under the emerging Indonesian democracy, this phenomenon has posed a serious question not only to Papua but also to the whole construct of the Indonesian state. The question is whether the Indonesian state will continue to respond with coercive governance in Papua whenever any sign arises and is considered posing a threat to national stability.

Learning from Papua's experience, any reform agenda should go beyond law, politics and the security sector. It should be able to address the cyclical production of meaning that has enabled torture as the mode of governance. It must advance a politics of the alternative, a liberation politics. Understanding torture in Papua is the beginning of acknowledging the reality of suffering among Papuans.

\section{References}

Alagappa, Muthiah 2001. 'Investigating and Explaining Change: An Analytical Framework'. In M. Alagappa (ed), Coercion and Governance: the Declining Political Role of the Military in Asia. Stanford University Press: Stanford, 29-68.

Alua, Agus A. 2000. Papua Barat dari Pangkuan ke Pangkuan Suatu Ikhtisar Kronologis, 2nd edn. Seri Pendidikan Politik Papua, Biro Penelitian STFT Fajar Timur, Jayapura.

Araf, Al, Aliabbas, Anton, Manto, Ardi, Reza, Bhatara Ibnu, Satriya, Cahyadi, Mahruri, Ghufron, Nurhasya, Jaky, Simun, Junaidi, Safa'at, Muchamad Ali and Indarti, Poengky 2011. Sekuritisasi Papua: Implikasi Pendekatan Keamanan terhadap Kondisi HAM di Papua. Jakarta: Imparsial.

Aspinall, Edward 2006. 'Violence and Identity Formation in Aceh under Indonesian Rule'. In A. Reid (ed), Verandah of Violence: The Background to the Aceh Problem. Singapore and Seattle: National University of Singapore Press and University of Washington Press, 149-176.

Boot, Machteld 2002. Genocide, Crimes Against Humanity, War Crimes: Nullum Crimen Sine Lege and the Subject Matter Jurisdiction of the International Criminal Court. Antwerpen, Oxford, New York: Intersentia. 
From 'Stone-Age' to 'Real-Time'

CAVR 2005. Chega! The Report of the Commission for Reception, Truth, and Reconciliation Timor-Leste. Dili: The Commission for Reception, Truth, and Reconciliation Timor-Leste (CAVR).

Chauvel, Richard 2005. Constructing Papuan Nationalism: History, Ethnicity, and Adaptation, Policy Studies 14. Washington D.C: East-West Center Washington.

Chauvel, Richard and Bhakti, Ikrar Nusa 2004. The Papua Conflict: Jakarta's Perceptions and Policies, Policy Studies 5. Washington D.C.: East-West Center Washington.

Cholil, M. 1971. Sedjarah Operasi2 Pembebasan Irian Barat. Jakarta: Pusat Sejarah ABRI.

Cohen, Stanley 2001. States of Denial: Knowing about Atrocities and Suffering. Cambridge: Polity Press.

Dean, Mitchell 2010. Governmentality: Power and Rule in Modern Society, 2nd edn. London: Sage.

Dershowitz, Alan Morton 2002. Why Terrorism Works: Understanding the Threat, Responding to the Challenge. New Haven and London: Yale University Press.

Diken, Bülent \& Lausten, Carsten Bagge 2005. 'Becoming Abject: Rape as a Weapon of War'. Body and Society 11(1): 111-128.

Dinas Sedjarah Militer Kodam XVII/ Tjendrawasih 1971. Irian Barat dari Masa ke Masa. Djajapura: Dinas Sedjarah Militer Kodam XVII/ Tjendrawasih.

Drooglever, Pieter 2009. An Act of Free Choice, Decolonization and the Right to Self-Determination in West Papua. Oxford: One Word.

Foucault, Michel 1982. 'The Subject and Power'. Critical Inquiry 8(4): 777-795.

Foucault, Michel 1991. Discipline and Punish: The Birth of Prison. London: Penguin Books.

Foucault, Michel 2003. 'Society Must Be Defended': Lectures at the College de France. New York: Picador.

Graziano, Frank 1992. Divine Violence, Spectacle, Psychosexuality, \& Radical Christianity in the Argentine 'Dirty War'. Boulder, San Francisco, Oxford: Westview Press.

Greenberg, Karen J., and Dratel Joshua L. (eds) 2005. The Torture Papers: The Road to Abu Ghraib. Cambridge: Cambridge University Press. 
Hansen, Thomas Obel 2011. 'The Policy Requirement in Crimes Against Humanity: Lessons from and for the Case of Kenya'. The George Washington International Law Review 43(1): 1-41.

Human Security Research Group 2012. Human Security Report 2012: Sexual Violence, Education, and War Beyond the Mainstream Narrative. Vancouver: Simon Fraser University.

Kelman, Herbert C. 2005. 'The Policy Context of Torture: A Social-Psychological Analysis'. International Review of the Red Cross 87(587): 123-134.

Kirsch, Stuart 2010. 'Ethnographic Representation and the Politics of Violence in West Papua'. Critique of Anthropology 30(1): 3-22.

Komnas Perempuan 2010. Stop Sudah! Kesaksian Perempuan Papua Korban Kekerasan dan Pelanggaran HAM 1963-2009. Komisi Nasional Anti Kekerasan terhadap Perempuan, Majelis Rakyat Papua. Jakarta: ICTJ.

Kristeva, Julia 1982. Powers of Horror: An Essay on Abjection. Trans. Roudiez, Leon. New York: Columbia University Press.

Kristeva, Julia 2002. Revolt, She Said. Cambridge, MA and London: MIT Press.

Levinson, Sanford (ed.) 2004. Torture: a Collection. Oxford: Oxford University Press.

Mietzner, Marcus 2009. Military Politics, Islam and the State in Indonesia. Singapore: ISEAS.

Morton, Stephen and Bygrave, Stephen (eds) 2008. Foucault in an Age of Terror: Essays on Biopolitics and the Defence of Society. New York: Palgrave Macmillan.

Nowak, Manfred 2008. Report of the Special Rapporteur on torture and other cruel, inhuman or degrading treatment or punishment, Addendum, Mission to Indonesia. New York: United Nations General Assembly.

Post, Jerrold M. and Panis, Lara K. 2011. 'Crimes of Obedience: "Groupthink" at Abu Ghraib'. International Journal of Group Psychotherapy 61(1): 49-66.

Pusat Sejarah dan Tradisi TNI 2000. Sejarah TNI Jilid I (1945-1949). Jakarta: Markas Besar Tentara Nasional Indonesia Pusat Sejarah dan Tradisi TNI.

Putro, RAP 2012. The Professionalism of the Indonesian Military. PhD thesis, University of New South Wales.

Rahmany, Dyah P. 2001. Matinya Bantaqiah, Menguak Tragedi Beutong Ateuh. Banda Aceh: Cordova. 
From 'Stone-Age' to 'Real-Time'

Reiffel, Alexis and Pramodhawardhani, Jaleswari 2007. Out of Business and On Budget: The Challenge of Military Financing in Indonesia. Washington D.C.: The Brookings Institution.

Rejali, Darius 2007. Torture and Democracy. Princeton and Oxford: Princeton University Press.

Rothenberg, Daniel 2003. "What We have Seen has been Terrible": Public Presentational Torture and the Communicative Logic of State Terror'. Albany Law Review 67(2): 465-499.

Rutherford, Danilyn 2012. Laughing at Leviathan: Sovereignty and Audience in West Papua. Chicago and London: The University of Chicago Press.

Saltford, John 2003. The United Nations and the Indonesian Takeover of West Papua, 1962-1969, The Anatomy of Betrayal 1st edn. London and New York: RoutledgeCurzon.

Scarry, Elaine 1985. The Body in Pain: The Making and Unmaking of the World. Oxford: Oxford University Press.

Schabas, William A. 2006. The UN International Criminal Tribunals: The Former Yugoslavia, Rwanda and Sierra Leone. Cambridge: Cambridge University Press.

Skjelbæk, Inger 2012. The Political Psychology of War Rape: Studies from Bosnia and Hersegovina. London and New York: Routledge.

Soeharto 1989. Soeharto: Pikiran, Ucapan dan Tindakan Saya: Otobiografi seperti Dipaparkan kepada G. Dwipayana dan Ramadhan K.H. Jakarta: PT Citra Lamtoro Gung Persada.

Soekarno 1962. Pembebasan Irian Barat: Kumpulan Pidato dan KeteranganKeterangan mengenai Perdjuangan Pembebasan Irian Barat dari 17 Agustus 1961 sampai 17 Agustus 1962, Djakarta: Departemen Penerangan R.I.

Taylor, Diana 1997. Disappearing Acts: Spectacles of Gender and Nationalism in Argentina's 'Dirty War'. Durham and London: Duke University Press.

Treib, Oliver, Bähr, Holger and Falkner, Gerda 2007. 'Modes of Governance: Towards a Conceptual Clarification'. Journal of European Public Policy 14(1): 1-20.

Vlasblom, Dirk 2004. Papoea: een Geschiedenis. Uitgevers: Mets \& Schilt.

Yamin, Muhammad. 1956. Kedaulatan Indonesia atas Irian Barat: Jaitu Uraian tentang Tuntutan Rakjat terhadap Wilajah Indonesia bagian Irian-Barat. Bukittinggi: Nusantara. 
This text is taken from From 'Stone-Age' to 'Real-Time': Exploring Papuan Temporalities, Mobilities and Religiosities, edited by Martin Slama and Jenny Munro, published 2015 by ANU Press, The Australian National University, Canberra, Australia. 